CHAPTER 4

\title{
POLITICAL MEMBERSHIP AND DEMOCRATIC BOUNDARIES
}

\section{RAINER BAUBÖCK}

\begin{tabular}{lc}
\hline Introduction & 60 \\
The Boundary Problem in Political Theory & 61 \\
Citizenship as Membership & 65 \\
Political Community and the Variety of Polities & 67 \\
The Mismatch between Territorial and Membership Boundaries & 72 \\
Conclusions & 78
\end{tabular}

\section{INTRODUCTION}

Democratic polities have boundaries that distinguish them from each other. These boundaries are of two different kinds. Geographic borders separate territorial jurisdictions and membership boundaries determine who is a citizen of which polity. Political theorists have recently been quite busy discussing the 'democratic boundary problem. In a nutshell, the problem is that the democratic legitimacy of decisions affecting the boundaries of a 'demos' (i.e. those citizens who are eligible to participate in democratic self-government) presupposes that the demos by whom 
or on whose behalf a decision is taken is already composed in a way that makes its boundaries legitimate. In the first section I claim that this problem is not merely a philosophical puzzle but has implications for citizenship boundaries in the real world. I then discuss general conceptual properties of membership boundaries and structural characteristics of political ones. The final section considers the political challenges that arise if citizenship boundaries do not match territorial ones. The conclusion reflects on the need for contextualizing the boundary problem.

This chapter examines citizenship primarily from the perspective of democratic theory. Its scope is therefore generally restricted to democratic states. This is not meant to ignore that the external function of citizenship as 'nationality' in the international state system applies to all modern states independently of their internal political regimes. I also acknowledge that democratic practices of citizenship exist in non-democratic states. ${ }^{1}$ My focus here is on the normative idea that democracy is a form of collective self-government in which citizens authorize governments and hold them accountable.

\section{The Boundary Problem in Political Theory}

Should a citizenship acquired at birth determine people's right to access economic opportunities or political liberties in other states' territories? ${ }^{2}$ Do those who have settled outside their country of citizenship have a right to retain that status forever and pass it on to their children? Should they also be allowed to determine the future of that country through casting absentee votes in elections? Does the right of states to determine who their own citizens are include a power to bestow their citizenship on populations in other states and to claim subsequently personal jurisdiction over them? If a majority of citizens residing in a part of a state territory desire to form their own state or join a neighbouring one, do they have a right to unilateral secession? These are only some of the normative questions about citizenship boundaries that arise in the real world of contemporary democratic states. In spite of the bewildering complexity of these questions, political theorists have tried to come up with general normative principles that aim to address the boundary problem.

\footnotetext{
${ }^{1}$ See Isin in this volume.

2 Ayelet Shachar, The Birthright Lottery: Citizenship and Global Inequality (Cambridge: Harvard University Press, 2009).
} 
Most theorists agree today that the problem cannot be resolved if we understand democracy merely as a set of procedures such as majority voting. As Robert Goodin points out: 'It is simply incoherent to constitute the electorate through a vote among voters who would be entitled to vote only by virtue of the outcome of that very vote. ${ }^{3}$ This does not mean, however, that there is no democratic answer. Instead of searching for solutions in democratic methods, we need to examine substantive conceptions of democracy and their underlying values and principles. ${ }^{4}$

Initially, the most widely discussed and endorsed principle was that all those whose interests are affected by a political decision ought to be included in the demos that takes this decision. In a seminal essay Fredrick Whelan already pointed out that the question of who is affected by a given law or policy depends on which law or policy is enacted from among the available alternatives' and concluded that the 'all affected' principle is 'a logical and procedural impossibility.' Robert Goodin's defence of the principle bites the bullet: 'Membership in the demos ought to extend to every interest that would probably be affected by any possible decision arising out of any possible agenda. ${ }^{6}$ His conclusion is that the only legitimate demos is a global one that includes everybody. Including all affected interests requires a democratic world government. As a second-best solution, a federal world state might delegate some of its power to states and, as a third-best, independent states ought to offer compensation where their decisions affect external interests negatively. ${ }^{7}$

In an influential early statement of the boundary problem Robert Dahl proposes a somewhat different principle: ' $[T]$ he demos should include all adults subject to the binding collective decisions of the association.8 Although Dahl remains ambiguous about whether he considers this principle as different from including 'all affected interests', a majority of contemporary theorists endorse a principle of 'including all subject to coercion.' ${ }^{\prime}$

The disagreement between the two schools is rooted in different conceptions of democratic legitimacy. For Goodin, the task of democratic government is

${ }^{3}$ Robert Goodin, 'Enfranchising All Affected Interests, and Its Alternatives', Philosophy and Public Affairs 35, no. 1 (2007): pp. 40-68, p. 43.

${ }^{4}$ David Miller, 'Democracy's Domain', Philosophy and Pulbic Affairs 37, no. 3 (2009): pp. 201-228, pp. 203-204.

${ }^{5}$ Frederick G. Whelan, 'Prologue: Democratic Theory and the Boundary Problem', in J. R. Pennock and J. W. Chapman, eds., NOMOS 25: Liberal Democracy (New York: New York University, 1983), p. 19.

${ }^{6}$ Goodin (n 3), pp. 61-62. $\quad{ }^{7}$ Ibid., pp. 64-67.

8 Robert Dahl, Democracy and Its Critics (New Haven: Yale University Press, 1989), p. 120.

9 See, e.g., Sofia Näsström, 'The Legitimacy of the People', Political Theory 35, no. 5 (2007); Nancy Fraser, Scales of Justice: Reimagining Political Space in a Globalizing World (New York: Columbia University Press, 2009); Seyla Benhabib, Dignity in Adversity: Human Rights in Troubled Times (Cambridge: Polity Press, 2011); David Owen, 'Constituting the Polity, Constituting the Demos: On the Place of the All Affected Interests Principle in Democratic Theory and in Resolving the Democratic Boundary Problem', Ethics and Global Affairs 5, no. 3 (2012): pp. 129-152; Michael Blake, 'Immigration, Jurisdiction, and Exclusion', Philosopy and Public Affairs 41, no. 2 (2013), no. 2 (2013): pp. 103-130. 
'protecting and promoting people's interests. ${ }^{10}$ With other utilitarian philosophers he regards government as a device for enabling the broadest possible satisfaction of individual interests. By contrast, most liberal and republican authors emphasize that governments (including democratic ones) are inherently coercive. Their legitimacy depends on securing individual and collective freedom through representing all those coerced in the making of the laws that will bind them.

At first glance, a principle of including all who are subjected to coercive government power seems to lead to a much narrower range of inclusion. Since the principle starts from existing territorial jurisdictions, it appears to justify the inclusion of all current residents in a polity and only these. In other words, it lends prima facie support to universal jus domicilii, as opposed to birthright citizenship or naturalization for which immigrants have to apply. Immigrants should be automatically included in the demos ${ }^{11}$ while emigrants should lose their right to vote and arguably also their citizenship status. ${ }^{12}$

However, as Arash Abizadeh points out, immigration laws are coercive towards those who are not admitted; potential immigrants (i.e. the rest of the world) should therefore be included in the demos that adopts these laws. This move could be understood as a reductio ad absurdum, but Abizadeh's conclusion is instead similar to Goodin's: a demos is only legitimate if it is in principle unbounded. ${ }^{13}$

David Miller attacks this conclusion by challenging the idea that immigration control is coercive as long as people have opportunities to enter elsewhere. ${ }^{14}$ Alternatively, one can escape the paradox that exclusion at the border is a coercive act that requires prior inclusion by specifying that only persistent subjection to coercive government makes people interdependent and creates a potential for domination that counts as relevant for purposes of democratic inclusion. ${ }^{15}$ This still leaves another problem unresolved. Why did colonialism not result in claims for inclusion but for independence? There must be a prior reason why certain populations have a right to territorial self-government ${ }^{16}$ before one can determine whom they ought to include in their citizenry.

${ }^{10}$ Goodin (n 3), p. 50.

${ }^{11}$ Ruth Rubio-Marín, Immigration as a Democratic Challenge: Citizenship and Inclusion in Germany and the United States (Cambridge: Cambridge University Press, 2000).

${ }_{12}$ See Claudio López-Guerra, 'Should Expatriates Vote?', The Journal of Political Philosophy 13, no. 2 (2005): pp. 216-234 for an early defence of this conclusion.

${ }_{13}$ Arash Abizadeh, 'Democratic Theory and Border Coercion: No Right to Unilaterally Control Your Own Borders', Political Theory 36, no. 1 (2008): pp. 37-65. For a similar conclusion see Näsström (n 9).

${ }_{14}$ David Miller, 'Why Immigration Controls are Not Coercive: A Reply to Arash Abizadeh', Political Theory 38, no. 1 (2010) pp: 111-120.

15 See, e.g., Iseult Honohan, Civic Republicanism (London and New York: Routledge, 2002).

16 Anna Stilz, 'Nations, States, and Territory', Ethics 121, no. 3 (2011): pp. 572-601; Cara Nine, Global Justice and Territory (Oxford: Oxford University Press, 2012); Oliviero Angeli, Cosmopolitanism, SelfDetermination and Territory: Justice with Borders (Houndsmills, Basingstoke: Palgrave Macmillan, 2015); Margaret Moore, A Political Theory of Territory (Oxford: Oxford University Press, 2015). 
More generally, it is not clear how the 'all subjected to coercion' principle can escape the circular reasoning at the core of the democratic boundary problem. Just as an election cannot determine who ought to be enfranchised in the very same election, it seems also incoherent to say that the legitimate demos includes all subjected to coercion by a government that must itself first be authorized by the very same demos.

Some theorists resolve the problem by pointing to a pre-political social community that provides historically given boundaries for the citizenry. Nations are the obvious candidates for such a view. ${ }^{17}$ One problem with this view is that it provides justification for different standards of inclusion in democratic states depending on their history of nation-building; settler nations may regard immigrants as future citizens while those that have emerged from the breakup of multinational empires do not. Joseph Carens proposes 'social membership' as an alternative criterion for determining the claims of immigrants to citizenship inclusion, ${ }^{18}$ but here again the boundaries of society are essentially those of residence within a given territorial jurisdiction, so the problem how to justify these boundaries vis-à-vis emigrants' claims to remain included and separatists' claims to change the borders remain unaddressed.

I have proposed that including all affected interests and all subjected to coercion call for taking affected interests into account in policy decisions and for providing equal protection of the law to all subjected to it. However, these principles are misapplied when considered as solutions of the boundary problem. ${ }^{19}$ As a distinct principle for citizenship inclusion I have proposed that those and only those individuals have a claim to membership in a self-governing political community whose autonomy and well-being depend on the collective self-government and flourishing of a particular polity. This 'citizenship stakeholder' principle assumes a relational correspondence between the normative reasons why individuals have a claim to membership and those why political communities have a claim to self-government. In order to apply it to real-world contexts, we need to match the links that tie individuals to a particular polity with the conditions under which that polity can be self-governing. These ties and conditions differ for independent states, local munieipalities, and supranational political unions and their citizenship rules must vary accordingly. Before exploring such variation, we need to establish first what all these different contexts have in common that makes it possible to compare them. In other words, we need to clarify conceptually what we mean by a citizenship boundary before examining how such boundaries differ across types of polities.

${ }_{17}$ David Miller, 'Immigrants, Nations, and Citizenship', The Journal of Political Philosophy 16, no. 1 (2008): pp. 371-39o.

${ }^{18}$ Joseph H. Carens, The Ethics of Immigration (Oxford: Oxford University Press, 2013).

19 Rainer Bauböck, 'Morphing the Demos into the Right Shape. Normative Principles for Enfranchising Resident Aliens and Expatriate Citizens', Democratization 22, no. 5 (2015): pp. 820-839. 


\section{Citizenship as Membership}

Citizenship is a membership-based concept. It means many other things too, but all interpretations of citizenship need to rely (explicitly or implicitly) on its conceptual core, which is membership in a political community.

Membership is a categorical and relational concept. From the internal perspective of a group, membership has a binary quality — it serves to distinguish insiders from outsiders. ${ }^{20}$ From the external perspective of an observer or the wider society, it serves to distinguish not merely individuals but also membership groups of the same kind by marking their boundaries.

As a relational concept membership necessarily relates an individual or group to a larger social entity. This relation can be described as inclusion. Membership is semantically different from concepts such as belonging or identity that are not inherently categorical distinctions but are generally used to express the strength of an attachment or of an individual or collective characteristic. Like membership, belonging is a relational concept but it can also be used to express an attachment to something that is not a social entity: one may have a sense of belonging to a natural environment but cannot be a member thereof. Identity is a concept that serves primarily to draw a contrast. Identities allow people to categorize themselves and others but the concept need not imply affiliation to any particular entity: hermits form an identity category but are not affiliated to any corresponding group or community. Membership is thus not just a formal relation between an individual and a social category but a status that individuals or groups enjoy within an entity that has some 'social life' of its own. Membership status can only be generated through (formal or informal) recognition by others. I cannot be a member of a group none of whose members recognizes me as a member.

Membership is a binary concept only with regard to the internal relation between one individual and one social entity at one point in time. It does not imply singularity. Individuals can be serially or simultaneously members in many different social entities, each of which maintains a clear binary distinction between members and non-members. Rogers Brubaker has characterized citizenship as an international filing system, a mechanism for allocating persons to states. ${ }^{21} \mathrm{~A}$ filing system operationalizes categorical and singular relations: each item is sorted into one file and one file only. This reflects, however, a peculiar 'Westphalian' conception of citizenship and is not implied when we characterize citizenship as a membership concept. Individuals can be citizens of several polities over the course of their lives, they can

\footnotetext{
${ }^{20}$ Rogers W. Brubaker, Citizenship and Nationhood in France and Germany (Cambridge: Harvard University Press, 1992).

${ }^{21}$ Ibid., p. 31.
} 
be multiple citizens of independent polities and they can be multilevel citizens of polities that are nested within other polities like Russian dolls.

The criteria for distinguishing members from non-members are not always entirely internal ones. Political membership boundaries have often been defined in class, gender, ethnic, religious, or racial terms, i.e. by referring to non-political boundaries that serve as reference frames for determining who can be a citizen and participate in politics. ${ }^{22}$ Such intersectionality is a frequent feature of membership boundaries but not a necessary one. For example, it is certainly true that in the current international system citizenship serves to preserve huge social inequalities between states by attaching membership to circumstances of birth and by giving states the power to exclude non-citizens from their territory. ${ }^{23}$ However, this is not an inherent feature of birthright citizenship but rather a political effect of global social inequalities. In the European Union weaker disparities and political integration have created conditions for free movement while citizenship remains firmly anchored in the member states' birthright regimes.

Categorical membership also does not entail that the boundary separating members from non-members is a hard one. Some memberships may be difficult to obtain whereas others are easily accessible; some memberships are attributed automatically at birth or to those who deliver a service or take up residence in a territory while in other cases, individuals must express their consent or apply actively.

Finally, categorical membership boundaries can also be blurred through statuses of quasi- or semi-membership. This may seem incoherent, but it is not as long as there is a core membership that can be distinguished from the quasi- or semi-statuses. Designating someone as a quasi-member does not turn membership itself into an ordinal concept that expresses degrees of a quality (of membership); it serves instead to maintain a binary distinction between members and quasimembers. ${ }^{24}$ The latter are often those who enjoy some of the benefits or bear some of the duties associated with membership without being recognized as members. Conversely, we can call individuals semi-members if they are formally recognized as members but deprived of some rights and obligations that are otherwise shared by members. ${ }^{25}$ Non-resident citizens are mostly semi-members because they cannot enjoy those citizenship rights that presuppose residence, whereas non-citizen

\footnotetext{
${ }^{22}$ For a discussion how the categorical distinctions of citizenship, gender, race, ethnicity, and religion interact with social inequality see Rogers Brubaker, Grounds for Difference (Cambridge: Harvard University Press, 2015).

${ }^{23}$ Joseph H. Carens, 'Aliens and Citizens: The Case for Open Borders', The Review of Politics 49, no. 2 (1987): pp. 251-273; Shachar (n 2); Brubaker (n 22), pp. 19-21.

${ }^{24}$ See Smith in this volume.

${ }^{25}$ Elizabeth F. Cohen, Semi-Citizenship in Democratic Politics (Cambridge: Cambridge University Press, 2010).
} 
residents are quasi-citizens (or 'denizens') ${ }^{26}$ if they enjoy most of the rights of citizens without sharing their legal status.

Because of its categorical nature, membership serves to create and maintain a boundary between a social entity and similar ones in its environment. Membership boundaries are soft or hard depending on how easy it is for individuals to cross them by taking up a new membership. This is obviously a matter of degree, but that does not affect the categorical nature of the distinction-just as territorial borders can be open or closed for migration without this affecting the territorial jurisdiction of the states that they separate. Plural and intersecting memberships, quasi- and semimemberships are a stronger challenge since they blur the boundary between a social entity and other entities of the same kind in its environment. ${ }^{27}$ Yet, as I have argued above, even in these cases an internally binary distinction continues to provide the hard core without which the very concept of membership loses its purpose.

The final feature of membership boundaries that is highly relevant for those of citizenship is their stability over time. Stability is again not about how hard a boundary is, but about whether the criterion of distinction and scope of inclusion remains the same over time and whether the members perceive themselves as a group that retains a distinct identity over time. Unstable boundaries are those that shift through or shrinking, illustrated by secession or unification of political territories but also by fundamental changes in citizenship rules that include or exclude broadly defined categories, for example through newly introducing jus soli in a country of immigration.

\section{Political Community and the Variety of Polities}

In all respects discussed so far, citizenship is not essentially different from membership in organisations, associations, congregations, corporations, and other kinds of

\footnotetext{
${ }^{26}$ Tomas Hammar, Democracy and the Nation State. Aliens, Denizens and Citizens in a World of International Migration (Aldershot: Avebury, 1990).

${ }^{27}$ See Rainer Bauböck, 'The Crossing and Blurring of Boundaries in International Migration. Challenges for Social and Political Theory', in Rainer Bauböck and John Rundell, eds., Blurred Boundaries. Migration, Ethnicity, Citizenship (Aldershot: Ashgate, 1998), pp. 17-52; Aristide Zolberg and Long Litt Woon, 'Why Islam is like Spanish: Cultural Incorporation in Europe and the United States', Politics \& Society 27, no. 1 (1999): pp. 5-38; Richard Alba, 'Bright vs. Blurred Boundaries: SecondGeneration Assimilation and Exclusion in France, Germany, and the United States', Ethnic and Racial Studies 28, no. 1 (2005): pp. 20-49. Andreas Wimmer, Ethnic Boundary Making: Institutions, Power, Networks (Oxford: Oxford University Press, 2013).
} 
social entities that populate 'civil society'. What is specific about citizenship is that it is about membership in a political community.

The notion of 'citizenship' is often also used in a loose sense when referring to rights, obligations, virtues, or practices of individuals or organizations in relation to other social entities. But all such uses are parasitical on a core idea of membership in a political community. They attribute to an entity qualities similar to those of political communities - for example, 'citizenship' in an academic institution refers to the idea that universities have a degree of collective autonomy, that faculty members have equal standing in collective decisions, and that academic institutions pursue a common good to which its members are morally obliged to contribute. Alternatively, citizenship may also be metaphorically attributed to organisations, i.e. to legal rather than natural persons, who have ethical duties to contribute to the common good of a wider society, as the notion of 'corporate citizenship' suggests.

Political communities are organized around coercive political institutions that govern their members or they aspire to establish such institutions. The concept of 'political community' refers to members and their horizontal relations with each other whereas the term 'polity' focuses on the vertical relation between political institutions and those whom they govern. Citizenship normally entails both horizontal and vertical relations, but, as pointed out by Jean Bodin, a political community or 'commonwealth' may survive the destruction of its political institutions and loss of its territory as long as its members maintain their customary laws and aspire to achieve self-government as a distinct polity. ${ }^{28}$ In the absence of government institutions, however, 'citizenship in exile' is reduced to membership without legally guaranteed rights and enforced duties and membership itself becomes then a matter of individual choice between assimilation into the wider society and preservation of a diasporic identity.

Where citizenship is institutionalized, however, it is quite unlike membership in a voluntary association. All polities establish rules for an automatic attribution of citizenship that is independent of individual choice. These rules are of three kinds: membership can be derived from circumstances at birth (jus sanguinis or jus soli), from residence (jus domicilii), or from another citizenship. The 'citizenship clause' that opens the 14th amendment to the U.S. Constitution illustrates these three attribution mechanisms: 'All persons born or naturalized in the United States, and subject to the jurisdiction thereof, are citizens of the United States and of the State wherein they reside.' Birthright citizenship in the U.S. is based on unconditional jus soli. There is an additional rule of jus sanguinis for the second generation born abroad to an American citizen parent that is not included in the 14th amendment. The Constitution does, however, specify that Americans are not only citizens of the federation, but also of one of the fifty states. This latter status is derived from

${ }^{28}$ Jean Bodin, Six Books of the Commonwealth. Abridged and translated by M. J. Tooley (Oxford: Blackwell, 1576/1955). Book 1, Chapter 6. 
federal citizenship and the state of which they are citizens is determined through residence. All these modes of acquiring citizenship (jus soli and jus sanguinis for federal citizenship, jus domicilii and derivative citizenship for federal state citizenship) apply automatically. The only way of becoming a citizen that depends directly on individual choice is naturalization.

To a marginal extent individuals are still able to 'choose' citizenship indirectly by putting themselves in a position that entails automatic attribution. Birthright tourism in countries with unconditional jus soli is the best-known illustration. In ius sanguinis regimes, some migrant couples decide that one of them should naturalize so that their child will be a dual citizen by descent. Jus domicilii combined with free internal movement allows federal citizens to choose where to take up residence in order to benefit from a lower regional tax rate or better social welfare and public services. ${ }^{29}$ Derivative citizenship in the supranational European Union creates a strong incentive for third country nationals to acquire the citizenship of a member state in order to benefit from freedom of movement throughout the Union.

Global interdependence and technical innovations in transportation and communication have enhanced opportunities for individual choice driven by unequal instrumental value of citizenships within and across states. ${ }^{30}$ Yet it remains true that overwhelming majorities acquire their citizenship statuses without ever exercising individual choice. Why is that so? One explanation is that contemporary states have an interest in securing not only the stability of their territorial jurisdiction, but also of populations over whom they exercise power. They may be happy to admit tourists, travelling business people, and temporary migrants to their territory if these provide them with economic benefits, but they need to distinguish sojourners from citizens in order to claim a stable population base and be recognized as states. Automatic attribution of citizenship provides functional stability in this respect. The other reason has to do with the conditions for democratic self-government. If citizenship were predominantly a matter of individual choice, it would not only be difficult for governments to maintain coercively binding solutions to collective action problems but also for citizens to hold governments accountable. This imperative of boundary stability is characteristic for modern democratic states. The

\footnotetext{
${ }^{29}$ For economic models promoting competition between local jurisdictions on the basis of individual membership choice, see Charles Tiebout, 'A Pure Theory of Local Expenditure', Journal of Political Economy 64, no. 5 (1956): pp. 416-424; James Buchanan, 'An Economic Theory of Clubs', Economica 32, no. 125 (1965): pp. 1-14; Bruno Frey and Reiner Eichberger, The New Democratic Federalism for Europe: Functional, Overlapping, and Competing Jurisdictions (Cheltenham, UK: Edward Elgar, 1999).

${ }^{30}$ Peter Spiro, Beyond Citizenship. American Identity After Globalization (Oxford: Oxford University Press, 2008); Christian Joppke, Citizenship and Immigration (London: Polity, 2010); Ayelet Shachar, 'Picking Winners: Olympic Citizenship and the Global Race for Talent', Yale Law Journal 120, no. 8 (2011): pp. 2088-2139; Yossi Harpaz, 'Ancestry into Opportunity: How Global Inequality Drives Demand for Non-Resident European Union Citizenship', Journal of Ethnic and Migration Studies 41, no. 13 (2015): pp. 2081-2104.
} 
territorial borders of empires were rarely stable and their governments were not accountable to their subjects.

Yet even in the contemporary world, states are not the only polities and citizenship exists at different levels. Federations, such as the U.S., provide one illustration for institutionalized multilevel citizenship. ${ }^{31}$ It does not matter whether a federal constitution officially recognizes a distinct citizenship of its constitutive polities (variously called provinces, regions, cantons, republics, or states). Democratic federalism entails that both federal and constitutive level legislatures are directly elected and thus need to determine a respective demos whose members are eligible to vote. The same is true for local level self-government, which is exercised through locally elected municipal councils. At the supranational level, the European, the Andean, and Central American Parliaments are also directly elected and member states of Mercosur are currently moving from nominating national parliamentarians to direct elections for the Mercosur Parliament. Unlike the latter three, the European Parliament has extensive legislative powers. The political world is thus populated by a variety of territorial polities of different kinds, each of which should be understood as a potential or actual space for citizenship.

The rules for determining citizens vary between these types. In contemporary states, citizenship is initially determined by birthright (i.e. some combination of jus soli and jus sanguinis) and can then be changed subsequently through naturalization, voluntary renunciation, or involuntary withdrawal. Citizenship at the substate level is derived from federal level citizenship and determined through residence. EU citizenship is similarly derivative but in a bottom-up way from citizenship in the member states. ${ }^{32}$ As a legal status it is independent of residence and can also be held outside the territory of the Union, but many of the rights associated with the status can only be activated through cross-border movement or inside the EU..$^{33}$

Local citizenship is somewhat harder to pin down because it is rarely constitutionalized as a legal status. Let us therefore consider how it differs from regional citizenship in federations. One striking finding is that many democratic states have

\footnotetext{
${ }^{31}$ See Maas in this volume.

32 The only other contemporary case of bottom-up derivation seems to be Switzerland where citizenship in the confederation is formally derived from cantonal citizenship. However, in terms of substance, federal citizenship law alone determines acquisition of Swiss citizenship through birthright and loss through renunciation and withdrawal. The autonomy of the cantons is reduced to setting conditions for naturalization and federal law determines the minimum requirements. By contrast, EU law leaves member states fully free to regulate access to the common status of EU citizenship. Some constraints have been imposed by jurisprudence of the Court of Justice of the EU (CJEU) that required member states to recognize citizenship awarded by other such states (in Judgment of 7 July 1992, Micheletti v Delegación del Gobierno en Cantabria, C-369/90, ECR, ECLI:EU:C:1992:295) and to take EU law into account when withdrawal of nationality leads to a loss of EU citizenship (Judgment of 2 March 2010, Rottmann v Reistaat Bayern, C-135/o8, ECR, ECLI:EU:C:2010:104).

${ }^{33}$ See Strumia in this volume.
} 
disconnected voting rights in local elections from national citizenship by either extending the franchise to the nationals of specific other countries or to all residents independently of their national citizenship. ${ }^{34}$ Including non-citizens in the regional demos is, by contrast, rather exceptional.

A second relevant consideration is how local and national level self-government relate to each other. Federal systems are characterized by a combination of shared rule and divided rule between the nested polities. ${ }^{35}$ Their substate polities are not only self-governing but also involved in federal government (often through representation in a second chamber). Local self-government is instead generally just about divided rule through devolved powers over local matters. Moreover, local governments provide local public services and develop a local infrastructure, i.e. public goods that benefit all local residents and only these. Distinguishing between residents who are citizens and non-citizen serves no useful purpose for local governments that can neither control immigration into their territory nor provide diplomatic protection for their emigrants. Jus domicilii is therefore the appropriate rule for determining who are the local citizens. Normatively speaking, a requirement of national or European citizenship for exercising the local franchise is an arbitrary restriction of the proper composition of the local demos imposed by higher level governments. ${ }^{36}$

A final distinction which most political theorists fail to draw is between the demos and the citizenry. As suggested at the beginning of this chapter, the demos includes those who are entitled to participate actively in the self-government of a polity. For practical purposes, we can say that all individuals who enjoy active voting rights are members of the demos. In nineteenth-century democracies, women were considered dependent or passive citizens without voting rights. Today, there are three main categories who remain excluded from the demos: children below voting age in all democracies, and mentally disabled citizens or criminal offenders in many. Apart from these, the distinction between citizenry and demos is still salient for special territories or citizens residing abroad. U.S. citizens residing in the District of Columbia can vote in presidential elections but not for Congress; those in Puerto Rico, Guam, American Samoa, and the U.S. Virgin Islands do not have voting rights in any national election. Until the mid-twentieth century, citizens living abroad were nearly universally disenfranchised, whereas most democratic states include them now in the electorate. ${ }^{37}$ This global trend represents a significant

${ }^{34}$ See Shaw in this volume; Jean-Thomas Arrighi and Rainer Bauböck, 'A Multilevel Puzzle. Migrants' Voting Rights in National and Local Elections', European Journal of Political Research, online first, DOI: 10.1111/1475-6765.12176 (2016).

${ }^{35}$ Daniel Elazar, Exploring Federalism (Tuscaloosa: The University of Alabama Press, 1987).

${ }^{36}$ Rainer Bauböck, 'Reinventing Urban Citizenship', Citizenship Studies 7, no. 2 (2003): pp. 139-160.

${ }^{37}$ IDEA and IFE, eds., Voting from Abroad. The International IDEA Handbook (Stockholm and Mexico City: International Institute for Democracy and Electoral Assistance and Instituto Federal Electoral de Mexico, 2007); Michael Collyer, 'A Geography of Extra-Territorial Citizenship: Explanations of External Voting', Migration Studies 2, no. 1 (2014): pp. 55-72. 
recent shift of demos boundaries and it goes hand in hand with a simultaneous blurring of the boundaries of citizenship through toleration of dual nationality.

It seems obvious that excluding citizens from the demos needs to be justified. The case of minor children is least problematic, but even in this respect, some scholars and advocacy groups have suggested including them either through age-specific participation rights or vicariously through additional votes for their parents. ${ }^{38}$

This question takes us back to the heart of the democratic boundary problem. Since the demos cannot determine its own boundaries through democratic procedures, we need to imagine the citizenry as a self-reproducing political community with a stable identity across time. Human societies reproduce themselves through the sequence of generations and through co-residence in a territory. Minor children and mentally disabled persons are not merely individuals in need of protection by the state; they are members of a self-reproducing political community who share experiences of political membership with their parents and with others of their birth-cohort living in the same polity. National and local polities differ in how they reproduce themselves through birthright and residence but the imperative of including minor children as citizens is the same. If children and the mentally handicapped had to pass a citizenship test or decide at the age of majority whether they are interested in acquiring voting rights, then the demos would turn into a separate association of those who share cognitive abilities and a desire to participate in politics and these citizens would rule over the rest of society. ${ }^{39}$ Such a demos would not only lack stability, since it cannot guarantee its own reproduction over time, but also democratic legitimacy. Instead of conceiving of the members of the demos as the only full citizens, they should be regarded as trustees who represent not merely themselves but also those citizens who lack capacities for participating in elections.

\section{The Mismatch between Territorial AND MEMbERSHIP Boundaries}

Where borders are stable and people are sedentary, there is no mismatch between territorial and personal jurisdiction. ${ }^{40}$ But when people move across borders or when borders move across people, discrepancies emerge that raise questions about

38 See Donaldson and Kymlicka in this volume.

${ }^{39}$ For an argument that citizenship should generally be acquired at majority, see Costica Dumbrava, Nationality, Citizenship and Ethno-Cultural Belonging, Preferential Membership Policies in Europe (Houndmills, Basingstoke: Palgrave Macmillan, 2014).

${ }^{40}$ See Walker in this volume. 
the membership status of non-resident and non-citizen migrants, as well as about that of former citizens in now external territories and of previous non-citizens in newly independent or incorporated territories.

If membership is based on jus domicilii, the potential discrepancy is minimized and the problem largely disappears. Citizenship is then simply determined by current residence in a territory. Immigrants are no longer distinguished from natives and emigrants are treated as if they had never been members. In case of moving borders the membership of those who stay put follows the change of status of the territory after whatever period of residence is used for implementing jus domicilii. Personal jurisdiction will also rarely overlap between polities since only few people have multiple residences between which they frequently move back and forth. Even if they do, a criterion of principal domicile can identify the one polity that has a stronger claim to count the person as a citizen than any other.

Jus domicilii is therefore a rule that maintains a stable criterion of membership (even if individuals move in and out of this status) and avoids jurisdictional conflicts by constantly adapting citizenship boundaries to territorial ones. It seems uniquely suited for a world where individuals are highly mobile across territorial borders and where political borders can be easily modified. This may sound like a global utopia but it is an empirical generalization of local level polities in contemporary democratic states.

The international system of states is very different in this respect. Citizenship acquired at birth is normally maintained over a whole life, also by migrants who cross international borders. Conversely, immigrants do not automatically acquire the citizenship of their country of residence but need to apply for naturalization. Mostly they also have to meet other criteria apart from residence, such as income, criminal record, language, and civic knowledge tests. ${ }^{41}$ The strong global trend towards toleration of multiple citizenship in both sending and receiving countries greatly facilitates retaining citizenships of origin and allows emigrants to pass these on to children born abroad-in many cases even beyond the second generation. Because the basis of citizenship in independent states is birthright, enhanced mobility and accommodation thereof by states leads to outcomes that are entirely different from those for local citizenship. Instead of adjusting citizenship to territorial borders, the trend goes in the opposite direction of increasing mismatch, a tendency that is reinforced when liberal states disconnect rights from citizenship status and grant them to permanent residents who lack then instrumental incentives for naturalization. First generation immigrants often prefer such quasi-citizenship even to dual citizenship, especially if the institutions and public culture of the receiving country do not encourage them to become full citizens. Source countries of emigrants, on the other hand, encourage these to retain their citizenship status and

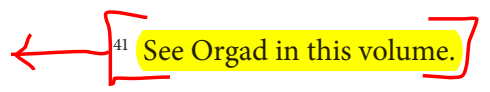


some offer their former citizens a status of external quasi-citizenship with rights to return and to own property. ${ }^{42}$

This increasing mismatch between territorial and membership boundaries is problematic for 'world state cosmopolitans' ${ }^{43}$ for whom independent states should be transformed into local provinces of a global polity whose borders are open and whose citizens pick up local memberships wherever they settle. If one accepts instead that states are and will remain those polities where self-government powers are most densely concentrated and that require birthright membership in order to stabilize their political communities, then the mismatch appears as a liberal blessing in disguise. Internal migrants who move between municipalities and provinces can rely on the protection of their rights by the higher level government of the state. International migrants must instead rely on dual protection by governments of origin and destination. ${ }^{44}$ In this context, migrants' rights are enhanced through opportunities to combine a nationality of origin with denizenship or full citizenship in the country of settlement.

Moreover, free movement across internal borders within states is a universal human right ${ }^{45}$ whereas free movement across international borders depends on citizenship. In the international state system, the asymmetry between a universal right to emigrate and a citizenship right to return to one's own country can be reduced through increasing toleration of multiple citizenship or through agreements between states to open their borders for each other's citizens-from visa waiver agreements to full access to settlement and employment, as in the EU, Mercosur, or the TransTasman Travel Agreement between Australia and New Zealand. Extending the geographic range and material scope of national citizenship rights seems thus the most promising route towards global free movement. ${ }^{46}$

Territorial boundary shifts are comparatively rare in the contemporary state system, where all territories apart from Antarctica have been demarcated as under one state's jurisdiction. ${ }^{47}$ Internal borders change more often when they are of mainly administrative nature but where they mark the territorial jurisdiction of a polity with self-government powers, changes are often politically contested precisely because they impact on regional or local citizenship boundaries.

Current international law does not recognize a right to unilateral secession from existing states. The principle of self-determination of people that is enshrined in the

${ }^{42}$ See Collyer in this volume. $\quad{ }^{43}$ See Tan in this volume.

${ }^{44} \mathrm{EU}$ citizens who migrate inside the EU are a mixed category in this respect. The protection of their rights by the higher level EU citizenship reduces their incentive to acquire dual citizenship.

${ }^{45}$ See Universal Declaration of Human Rights Art. 13 (1), International Covenant on Civil and Politial Rights Art. 12 (1).

${ }^{46}$ Rainer Bauböck, 'Migration and the Porous Boundaries of Democratic States', in Stephan Leibfried et al., eds., The Oxford Handbook of Transformations of the State (Oxford: Oxford University Press, 2014).

${ }^{47}$ See Walker in this volume. 
UN Charter and the human rights conventions has been generally interpreted as a right to self-government for the whole population of legitimate states rather than as a right of nations to their own independent states. ${ }^{48}$ After World War II, when colonialism came to be considered illegitimate, this principle grounded a right of colonies to independence within borders previously drawn by colonial administrations. After 1989, the break-up of European socialist states that had formally federal constitutions reinforced the principle of uti posseditis iuris, i.e. the maintenance of previous territorial borders that became transformed from federal into international ones. ${ }^{49}$ Independence for Kosovo and South Sudan, however, did not fully fit this pattern and was mainly justified on grounds of loss of legitimacy by central governments that engage in attempted genocide against a part of their population.

The fact that international law is conservative with regard to changes of international borders is unsurprising since it is based on agreements between and customary practices of existing states. It can therefore not be taken as a sufficient response to the normative question whether and on which grounds unilateral secession can be justified. Political theorists have debated this question intensely since the mid1980s. The answers that have emerged can be broadly grouped into three schools of thought. The first one regards democratic polities as voluntary territorial associations and suggests that any group of citizens who want independence for a specific territory has a primary right to secession if they win a majority in a plebiscite within that territory, as long as they are ready to grant the same right to any other group that challenges the integrity of the secessionist territory. ${ }^{50} \mathrm{~A}$ second school sees cultural nations rather than state peoples as the subjects of self-determination claims. Liberal nationalists ground this idea in the value of national membership for individual autonomy and well-being and in the support that a shared national identity provides for democratic and social solidarity among citzens. ${ }^{51}$ Inspired by John Stuart Mill's verdict that 'free institution are next to impossible in a country made up of different nationalities' ${ }^{52}$ some liberal nationalists believe that democracy requires a sense of shared nationhood. This does not rule out stable plurinational states if all national groups see themselves as sharing an overarching national identity but it does provide an argument for breaking up multinational states with

\footnotetext{
${ }^{48}$ Antonio Cassese, Self-Determination of Peoples. A Legal Reappraisal (Cambridge: Cambridge University Press, 1995).

49 Steven R. Ratner, 'Drawing a Better Line: Uti Possidetis and the Borders of New States', American Journal of International Law 9o, no. 4 (1996): pp. 590-624.

${ }^{50}$ Harry Beran, 'A Liberal Theory of Secession', Political Studies 32, no.1 (1984): pp 21-31; David Gauthier, 'Breaking Up: An Essay on Secession', Canadian Journal of Philosophy 24, no. 3 (1994): pp. 357-371.

${ }^{51}$ David Miller, On Nationality (Oxford: Oxford University Press, 1995); Will Kymlicka, Politics in the Vernacular: Nationalism, Multiculturalism, and Citizenship (Oxford: Oxford University Press, 2001). See also Gans in this volume.

${ }^{52}$ John Stuart Mill, 'Considerations On Representative Government', in H. B. Acton, ed., Utilitarianism, Liberty, Representative Government (London: Everymans Library, 1972), p. 392.
} 
a recent history of violent ethnonational conflict. ${ }^{53}$ Finally, a third group of theorists defends a 'remedial-only' right to secession if a state loses legitimacy because of oppression and discrimination of a territorial minority. ${ }^{54}$ On some accounts, grievance-based secession claims may not only be triggered by serious infringement of individual rights of minority members, but also by persistent violation of territorial self-government rights at substate level. ${ }^{55}$ On the one hand, this makes otherwise stable plurinational democracies vulnerable to potentially legitimate secession claims if they fail to recognize a historic minority's political autonomy. On the other hand, this argument supports also a duty of national minorities to respect the territorial integrity of a state that enables their self-government. In this view, national minorities need not share a common national identity with the rest of the population, but they must be able to see themselves as full citizens of both their self-governing territory and of the larger state.

The focus of this debate has been on justifications for secession rather than on its consequences, one of which is the need to redraw also the boundaries of citizenship. Even more than migration, which presupposes existing territorial citizenries and demoi whom migrants leave or join, territorial boundary shifts demonstrate that the democratic boundary problem does have practical relevance. There are two questions that secession raises in this respect: who should be the members of the demos that decides in a secession plebiscite or on behalf of whom secession is decided by a legislative body? And if secession is the outcome of such a decision, how should the citizenry of the newly formed state be determined? There is a body of international legal norms concerning the determination of citizenship in cases of state succession, ${ }^{56}$ but political theory has so far paid little attention to the difficult question of how citizenship ought to be reallocated when borders change.

With regard to the first question, there are three possible answers: the relevant demos could consist of all citizens of the current state that would suffer a loss of territory, of only those citizens who reside in the territory the status of which is being decided, or of all persons who have an immediate stake in the decision since they might lose their current citizenship or would potentially become the citizens of a new state if secession is the outcome. The current Spanish government and Constitutional Court endorse the first view, which allows national majorities to block secession. The Quebec and Scottish independence referendums were based on the second view. In the latter event, some scholars defended the third view, according to which those who might have become citizens of an independent Scotland

${ }^{53}$ David Miller, Citizenship and National Identity (Cambridge: Polity Press, 200o), pp. 125-141.

54 Allen Buchanan, Justice, Legitimacy, and Self-Determination. Moral Foundations for International Law (Oxford: Oxford University Press, 2004).

55 Alan Patten, Equal Recognition. The Moral Foundations of Minority Rights (Princeton: Princeton University Press, 2014), chapter 7.

56 See, e.g., European Convention on Nationality, chapter VI (CETS 166/1997). 
should have been entitled to vote. ${ }^{57}$ I will not attempt to provide an answer to this normative puzzle here because, unlike theorists defending a plebiscitary right to secession, I do not think there is a general answer that would be the same for secession inside a state (as in the creation of many new states in India since 1947 or the separation of the canton Jura from Berne in 1978/79), secession from a state, or secession of a state from a union (as in the case of Brexit). The context and level of citizenship matters for the composition of the demos also in decisions about the territorial shape and status of the polity.

The second question has again three possible answers the choice of which depends on context as well as normative considerations. ${ }^{58}$ If a new state is formed in a territory that has never previously enjoyed self-government, the only defensible solution is to grant citizenship to all those who have a right of residence when the polity becomes independent. This is sometimes called the 'zero solution' and it has been applied in most successor states of the Soviet Union. Estonia and Latvia chose, however, a different approach of 'citizenship restoration' which included those who had been citizens of the independent states before Soviet annexation and their descendants, but excluded internal migrants who had settled in the Baltic Soviet republics. ${ }^{59}$ Finally, the successor states of socialist Yugoslavia and Czechoslovakia referred to the previously merely nominal citizenship of the federal republics and converted them into citizenship of the newly independent states.

These three rules echo to a certain extent the general principles for determining individual citizenship. The zero solution could be interpreted as a version of jus domicilii, with the important difference that citizenship so acquired is not lost through subsequent emigration. It could therefore also be regarded as a form of jus soli that refers to the birth of the state rather than that of the individual. Restored citizenship harks back to the principle of jus sanguinis, especially if descendants of the original citizens are automatically included. And the upgrading of a substate citizenship relies on multilevel derivation-with the twist that it is now the derivative citizenship that gets elevated to the top. Finally, there is also an analogue to naturalization. The zero option is normally combined with option rights for individuals to choose a different citizenship than the one initially assigned to them. The important observation is, however, that the choice of rule for initial determination of citizenship does not predetermine the rules that characterize the subsequent regime for individual acquisition and loss of citizenship. Inclusion principles applied when constituting the polity are not necessarily the same as those for the

\footnotetext{
${ }^{57}$ Ruvi Ziegler, Jo Shaw, and Rainer Bauböck, 'Independence Referendums: Who should Vote and Who should be Offered Citizenship, EUI Working Paper RSCAS 2014/90', in Robert Schuman Working Paper (Florence: EUI, 2014).

${ }^{58}$ See Shevel in this volume.

${ }^{59}$ Rogers W. Brubaker, 'Citizenship Struggles in Soviet Successor States', International Migration Review 26, no. 2 (1992): pp. 269-291.
} 
ongoing determination of its membership and citizenship allocation in contexts of secession or migration follows different logics.

While secession and the formation of new states have remained relatively rare events, we need to be aware that internal mismatches of territorial and membership boundaries occur also short of full secession when territories have special status that entails restrictions of citizenship rights within the larger polity (as in the case of lack of federal voting rights for Puerto Rico or Washington D.C.) or special self-government rights not enjoyed by citizens residing in other parts of the state (as in the case of the Finnish Aland Islands or South Tyrol/Alto Adige in Italy). Asymmetries of this kind diminish equality of citizenship but may still be justified as an (often unstable) equilibrium between secession and oppressive denial of historic minority self-government claims.

\section{CONCLUSIONS}

This chapter has focused on citizenship as membership in a political community. I started with a critical discussion of attempts by political theorists to resolve the democratic boundary problem through a single principle of democratic inclusion that applies to all stages of the democratic process and all types of polities. I then investigated conceptual properties of citizenship, arguing that as a form of membership citizenship creates categorical distinctions but not necessarily impermeable, stable, or bright boundaries. Citizenship boundaries are exposed to processes of crossing, shifting, and blurring in contexts of migration, secession, and supranational integration. The third section examined the variety of democratic polities and identified birthright, residence, and multilevel derivation as the characteristic membership rules for independent states, for municipalities, and for subnational or supranational regions. The last section discussed the mismatch between territorial and membership boundaries in the international state system as the main reason for the increasing complexity of citizenship relations in the current world, but also as a potential source of protection and opportunities for those individuals whose lives connect them to several independent states. My conclusion is that normative inclusion principles need to be sensitive not only to the diversity of interests, beliefs, and values in liberal society, but also to the plurality of self-governing polities and of individuals' relations to these.

My discussion has relied on an implicit background assumption. It took for granted that both territorial borders and individual patterns of residence are 
relatively stable. It is this background that constitutes migration as the crossing of territorial borders of relatively sedentary societies and that makes it possible for these societies to adjust their political membership in response. In a hyper-mobile world where large majorities of people are only temporary residents in any political territory for most of their lives, the boundaries of citizenship would have to be radically reconstructed. ${ }^{60}$ We can imagine that such a world would have to combine universal jus domicilii in territorial jurisdictions with the constantly shifting boundaries of issue-specific non-territorial demoi whose composition is determined by individuals opting in and out according to their perceived identities and interests. It would be difficult to maintain the idea of citizenship as membership in a self-governing political community in such a world. We might be gradually moving towards it, but this does not entail that reforming democratic citizenship has become a futile task. Instead, democratic theorists and politicians would just have to think harder about how to internalize mobility within larger democratic polities such as supranational unions of states and how to involve immigrants and emigrants in today's territorially based democratic politics.

\section{BIBLIOGRAPHY}

Abizadeh, Arash, 'Democratic Theory and Border Coercion: No Right to Unilaterally Control Your Own Borders', Political Theory 36, no. 1 (2008): pp. 37-65.

Alba, Richard, 'Bright vs. Blurred Boundaries: Second-Generation Assimilation and Exclusion in France, Germany, and the United States', Ethnic and Racial Studies 28, no. 1 (2005): pp. 20-49.

Angeli, Oliviero, Cosmopolitanism, Self-Determination and Territory. Justice with Borders (Houndsmills, Basingstoke: Palgrave Macmillan, 2015).

Arrighi, Jean-Thomas, and Rainer Bauböck, 'A Multilevel Puzzle. Migrants' Voting Rights in National and Local Elections', European Journal of Political Research (online first, October 2016, DOI: 10.1111/1475-6765.12176).

Bauböck, Rainer, 'The Crossing and Blurring of Boundaries in International Migration. Challenges for Social and Political Theory', in Rainer Bauböck and John Rundell, eds., Blurred Boundaries. Migration, Ethnicity, Citizenship (Aldershot: Ashgate, 1998), pp. $17-52$.

Bauböck, Rainer, 'Reinventing Urban Citizenship', Citizenship Studies 7, no. 2 (2003): pp. $137-158$.

Bauböck, Rainer, 'Temporary Migrants, Partial Citizenship and Hypermigration', Critical Review of International Social and Political Philosophy 14, no. 5 (2011): pp. 665-693.

${ }^{60}$ See Rainer Bauböck, 'Temporary Migrants, Partial Citizenship and Hypermigration', Critical Review of International Social and Political Philosophy 14, no. 5 (2011): pp. 665-693. 
Bauböck, Rainer, 'Migration and the Porous Boundaries of Democratic States', in Stephan Leibfried et al., eds., The Oxford Handbook of Transformations of the State (Oxford: Oxford University Press, 2014), pp. 516-531.

Bauböck, Rainer, 'Morphing the Demos into the Right Shape. Normative Principles for Enfranchising Resident Aliens and Expatriate Citizens', Democratization 22, no. 5 (2015): pp. 820-839.

Benhabib, Seyla, Dignity in Adversity: Human Rights in Troubled Times (Cambridge: Polity Press, 2011).

Beran, Harry, 'A Liberal Theory of Secession', Political Studies 32, no. 1 (1984): pp. 21-31.

Blake, Michael, 'Immigration, Jurisdiction, and Exclusion', Philosopy and Public Affairs 41, no. 2 (2013): pp. 103-130.

Bodin, Jean, Six Books of the Commonwealth. Abridged and translated by M. J. Tooley (Oxford: Blackwell, 1576/1955).

Brubaker, Rogers, Grounds for Difference (Cambridge: Harvard University Press, 2015).

Brubaker, Rogers W., Citizenshipand Nationhood in Franceand Germany (Cambridge:Harvard University Press, 1992).

Brubaker, Rogers W., 'Citizenship Struggles in Soviet Successor States', International Migration Review 26, no. 2 (1992): pp. 269-291.

Buchanan, Allen, Justice, Legitimacy, and Self-Determination. Moral Foundations for International Law (Oxford: Oxford University Press, 2004).

Buchanan, James, 'An Economic Theory of Clubs', Economica 32, no. 125 (1965): pp. 1-14.

Carens, Joseph H., 'Aliens and Citizens: The Case for Open Borders', The Review of Politics 49, no. 2 (1987): pp. 251-273.

Carens, Joseph H., The Ethics of Immigration (Oxford: Oxford University Press, 2013).

Cassese, Antonio, Self-Determination of Peoples. A Legal Reappraisal (Cambridge: Cambridge University Press, 1995).

Cohen, Elizabeth F., Semi-Citizenship in Democratic Politics (Cambridge: Cambridge University Press, 2010).

Collyer, Michael, 'A Geography of Extra-Territorial Citizenship: Explanations of External Voting', Migration Studies 2, no. 1 (2014): pp. 55-72.

Dahl, Robert, Democracy and Its Critics (New Haven: Yale University Press, 1989).

Dumbrava, Costica, Nationality, Citizenship and Ethno-Cultural Belonging, Preferential Membership Policies in Europe (Houndmills Basingstoke: Palgrave Macmillan, 2014).

Elazar, Daniel Exploring Federalism (Tuscaloosa: The University of Alabama Press, 1987).

Fraser, Nancy, Scales of Justice: Reimagining Political Space in a Globalizing World (New York: Columbia University Press, 2009).

Frey, Bruno, and Reiner Eichberger, The New Democratic Federalism for Europe: Functional, Overlapping, and Competing Jurisdictions (Cheltenham, UK: Edward Elgar, 1999).

Gauthier, David, 'Breaking Up: An Essay on Secession', Canadian Journal of Philosophy 24, no. 3 (1994): pp. 357-372.

Goodin, Robert, 'Enfranchising All Affected Interests, and Its Alternatives', Philosophy and Public Affairs 35, no. 1 (2007): pp. 40-68.

Hammar, Tomas, Democracy and the Nation State. Aliens, Denizens and Citizens in a World of International Migration (Aldershot: Avebury, 1990). 
Harpaz, Yossi, 'Ancestry into Opportunity: How Global Inequality Drives Demand for NonResident European Union Citizenship', Journal of Ethnic and Migration Studies 41, no. 13 (2015): pp. 2081-2104.

Honohan, Iseult, Civic Republicanism (London and New York: Routledge, 2002).

IDEA, and IFE, eds., Voting from Abroad. The International IDEA Handbook (Stockholm and Mexico City: International Institute for Democracy and Electoral Assistance and Instituto Federal Electoral de Mexico, 2007).

Joppke, Christian, Citizenship and Immigration (London: Polity, 2010).

Kymlicka, Will, Politics in the Vernacular: Nationalism, Multiculturalism, and Citizenship (Oxford: Oxford University Press, 2001).

López-Guerra, Claudio, 'Should Expatriates Vote?', The Journal of Political Philosophy 13, no. 2 (2005): pp. 216-234.

Mill, John Stuart, 'Considerations On Representative Government', in H. B. Acton, ed., Utilitarianism, Liberty, Representative Government (London: Everymans Library, 1972).

Miller, David, On Nationality (Oxford: Oxford University Press, 1995).

Miller, David, Citizenship and National Identity (Cambridge: Polity Press, 200o).

Miller, David, 'Immigrants, Nations, and Citizenship', The Journal of Political Philosophy 16, no. 1 (2008): pp. 371-39o.

Miller, David, 'Democracy's Domain', Philosophy and Pulbic Affairs 37 (2009): pp. 201-228.

Miller, David, 'Why Immigration Controls are Not Coercive: A Reply to Arash Abizadeh', Political Theory 38, no. 1 (2010): pp. 111-120.

Moore, Margaret, A Political Theory of Territory (Oxford: Oxford University Press, 2015).

Näsström, Sofia, 'The Legitimacy of the People', Political Theory 35, no. 5 (2007): pp. 624-658.

Nine, Cara, Global Justice and Territory (Oxford: Oxford University Press, 2012).

Owen, David, 'Constituting the Polity, Constituting the Demos: On the Place of the All Affected Interests Principle in Democratic Theory and in Resolving the Democratic Boundary Problem', Ethics and Global Affairs 5, no. 3 (2012): pp. 129-152.

Patten, Alan, Equal Recognition. The Moral Foundations of Minority Rights (Princeton: Princeton University Press, 2014).

Ratner, Steven R., 'Drawing a Better Line: Uti Possidetis and the Borders of New States', American Journal of International Law 9o, no. 4 (1996): pp. 590-624.

Rubio-Marín, Ruth, Immigration as a Democratic Challenge: Citizenship and Inclusion in Germany and the United States (Cambridge: Cambridge University Press, 2000).

Shachar, Ayelet, The Birthright Lottery: Citizenship and Global Inequality (Cambridge: Harvard University Press, 2009).

Shachar, Ayelet, 'Picking Winners: Olympic Citizenship and the Global Race for Talent', Yale Law Journal 120, no. 8 (2011): pp. 2088-2139.

Spiro, Peter, Beyond Citizenship. American Identity After Globalization (Oxford: Oxford University Press, 2008).

Stilz, Anna, 'Nations, States, and Territory', Ethics 121, no. 3 (2011): pp. 572-601.

Tiebout, Charles, 'A Pure Theory of Local Expenditure', Journal of Political Economy 64 (1956): pp. 416-424.

Whelan, Frederick G., 'Prologue: Democratic Theory and the Boundary Problem', in J. R. Pennock and J. W. Chapman, eds., NOMOS 25: Liberal Democracy (New York: New York University, 1983), pp. 13-47. 
Wimmer, Andreas, Ethnic Boundary Making: Institutions, Power, Networks (Oxford: Oxford University Press, 2013).

Ziegler, Ruvi, Jo Shaw, and Rainer Bauböck, 'Independence Referendums: Who should Vote and Who should be Offered Citizenship ${ }_{\boldsymbol{R}}$ EUI Working Paper RSCAS 2014/90' in Robert Storence: EUI, 2014).

Zolberg, Aristide, and Long Litt Woon, 'Why Islam is Like Spanish: Cultural Incorporation in Europe and the United States', Politics \& Society 27, no. 1 (1999): pp. 5-38. 